\title{
Bacillus subtilis levansucrase: the efficiency of the second stage of secretion is modulated by external effectors assisting folding
}

\author{
Régis Chambert, El Arbi Haddaoui and Marie-Françoise Petit-Glatron
}

Author for correspondence: Régis Chambert. Tel: +331442747 19. Fax: +33144275994.

Institut Jacques Monod, CNRS/Université Denis Diderot (Paris 7),

Laboratoire Génétique et Membranes, Tour 43, 2 place Jussieu, 75251 Paris Cedex 05, France

\begin{abstract}
We investigated whether the concentration of $\mathrm{H}^{+}$or metal ions such as $\mathrm{Ca}^{2+}$, or both, on the external side of the cytoplasmic membrane is involved in coupling of folding and secretion of Bacillus subtilis levansucrase by studying the modulation of each isolated event. In vitro at $30{ }^{\circ} \mathrm{C}$, in the absence of $\mathrm{Ca}^{2+}$, the equilibrium between the unfolded and the folded states of levansucrase was rapidly and totally displaced toward the folded state by a small pH shift from $7 \cdot 4$ to $6 \cdot 0 . \mathrm{Ca}^{2+}$ ( $>5 \mathrm{mM}$ ) acted as a catalyst of folding at $\mathrm{pH} \geqslant 7$. In vivo pulsechase experiments at $30{ }^{\circ} \mathrm{C}$ showed that, in the absence of $\mathrm{Ca}^{2+}$, the rate and the yield of the second step of levansucrase secretion were strongly dependent on the external pH. In acidic growth medium (pH 5.8), secretion was efficient. In contrast, at $\mathrm{pH} \geqslant 7$, the presence of $\mathrm{Ca}^{2+}$ was essential for secretion. In bacteria grown at high temperature $\left(48{ }^{\circ} \mathrm{C}\right)$, both external acidic $\mathrm{pH}$ and $\mathrm{Ca}^{2+}$ were required for efficient secretion. Moreover, a levansucrase variant altered in its calcium affinity was efficiently secreted only under acidic growth conditions. Depending on the culture conditions, the differences in $\mathrm{H}^{+}$ or $\mathrm{Ca}^{2+}$ concentrations which are maintained between the opposite sides of the energized cytoplasmic membrane could be adequate to catalyse conformational transition which could play a critical role in the second step of the protein release. These environmental parameters could also affect the yield of secretion of some other secretory proteins, leading to the hypothesis that several different secretion mechanisms could coexist in B. subtilis.
\end{abstract}

Keywords: levansucrase, Bacillus subtilis, protein folding, protein secretion, folding catalysts

\section{INTRODUCTION}

Levansucrase is an extracellular enzyme synthesized by Bacillus subtilis during the exponential phase of growth. It is secreted by a two-step mechanism (Petit-Glatron $e t$ al., 1987). The first step of this mechanism consists of the proteolytic cleavage of the $\mathrm{N}$-terminal signal sequence to give a mature membrane-associated form. The second step, which is rate limiting, is the release and concomitant conformational change of the protein. We have suggested that the energy required for the vectorial diffusion of the protein from the membrane phase to the external aqueous phase (driven reaction) is provided by the energy change accompanying the folding process (driving reaction). The efficiency of such a hypothetical coupling could strongly depend on the rate of the driving reaction, as we previously proposed from an irreversible thermodynamic point of view (Chambert $e t$ al., 1990). This model predicts that changes in the external concentration of any effector that modulates protein folding will also affect the efficiency of the second step. We have recently shown that in addition to $\mathrm{Fe}^{3+}$ (Chambert et al., 1990), $\mathrm{Ca}^{2+}$ ions could also play such a role; these two metal ions catalyse in vitro the spontaneous folding of levansucrase at $\mathrm{pH} 7$ and can be concentrated within the cell wall in the microenvironment of the external side of the cytoplasmic membrane (Beveridge \& Murray, 1976, 1980; PetitGlatron et al., 1993).

In this work we focused our attention on the $\mathrm{H}^{+}$ion as a potential effector of folding and secretion, for several reasons. Preliminary studies have shown that the unfolding-folding transition of levansucrase is dependent on the ionization state of the protein within the physiological $\mathrm{pH}$ range (Chambert \& Petit-Glatron, 1990). The involvement of $\mathrm{H}^{+}$ions can be studied because their 
concentration on the external side of the membrane can be easily manipulated. At culture $\mathrm{pH}$ ranging from $5 \cdot 8$ to $7 \cdot 8$, $B$. subtilis grows normally and maintains its cytoplasmic $\mathrm{pH}$ unchanged near 7.4 (Khan \& Macnab, 1980; Shioi et al., 1980). This means that under acidic conditions of the culture medium, the $\mathrm{H}^{+}$concentration can be 200 times greater on the external side of the membrane than on the internal side.

Finally, effects of the transmembrane $\Delta \mathrm{pH}$ on the $B$. subtilis protein secretion process have been observed (Hemilä et al., 1992) but never clearly understood. Kemper et al. (1993) proposed that the cell wall may serve as a proton sink, causing the wall to have a relatively low $\mathrm{pH}$ in the immediate vicinity of the membrane. This may regulate cell-wall-associated enzymes in B. subtilis. From a thermodynamic point of view, it has been proposed that $\Delta \mathrm{pH}$ is involved in secretion via its participation in the proton-motive force which has been postulated to supply the energy for protein translocation in prokaryotes (Randall et al., 1987).

The question arises as to whether the proton concentration, per se, on the external side of the membrane promotes a spontaneous molecular event helping the protein vectorial translocation across the membrane. We here investigated the effect of $\mathrm{pH}$ on the in vitro unfolding-folding transition and on the in vivo efficiency of levansucrase secretion. Moreover, since we have demonstrated that $\mathrm{Ca}^{2+}$ ions can modulate both events under the usual $\mathrm{pH}$ growth conditions, i.e. pH 7 (PetitGlatron et al., 1993), we assessed the relative involvement of this metal ion and interactions, competition or cooperation, between these two cations in levansucrase secretion under various growth conditions.

\section{METHODS}

Enzymes, substrates and reagents. Subtilisin and ProteinA-Sepharose CL4B were from Sigma; $p$-nitrophenylmaltoheptaoside was purchased from bio-Merieux; $\left[{ }^{35} \mathrm{~S}\right]$ methionine, ${ }^{45} \mathrm{CaCl}_{2}$ and ${ }^{125} \mathrm{I}$-labelled protein $\mathrm{A}$ were from Amersham.

Purification of extracellular levansucrases. Levansucrase and its variant were purified from culture supernatants of induced strains QB112 and QB250 according to the procedure described by Dedonder (1966).

Purification of extracellular $\alpha$-amylase. $\alpha$-Amylase was purified from $B$. subtilis culture supernatant according to the method of Mäntsälä \& Zalkin (1979).

Levansucrase assay. The sucrase activity of levansucrase was assayed as described by Dedonder (1966). Glucose and fructose release from sucrose hydrolysis were measured by the method of Somogyi (1945).

$\alpha$-Amylase assay. $\alpha$-Amylase activity was assayed using $p$ nitrophenyl-maltoheptaoside as a substrate under the conditions recommended by the supplier.

Pulse-chase experiments. $B$. subtilis cells in the exponential phase of growth were pulse-chased with $\left[{ }^{35} \mathrm{~S}\right]$ methionine as described previously (Chambert \& Petit-Glatron, 1988).
Characterization of labelled transient membrane forms. Bacteria in the exponential phase of growth and induced for levansucrase synthesis ( $50 \mathrm{mM}$ sucrose final concentration) were labelled with $\left[{ }^{35} \mathrm{~S}\right]$ methionine $\left[0.25 \mathrm{mCi} \quad(9.25 \mathrm{MBq}) \mathrm{ml}^{-1}\right.$, $1000 \mathrm{Ci}(37 \mathrm{TBq}) \mathrm{mmol}^{-1}$. Samples $(0.4 \mathrm{ml})$ were withdrawn at intervals. All reactions were stopped by diluting the samples with 5 vols ice-cold stopping buffer $(0 \cdot 1 \mathrm{M}$ potassium phosphate, $\mathrm{pH} 7$, containing $2 \mathrm{M} \mathrm{KCl}, 200 \mu \mathrm{g}$ chloramphenicol $\mathrm{ml}^{-1}, 5 \mathrm{mM}$ EDTA and $0.2 \mathrm{mM}$ PMSF). The high-ionicstrength treatment releases any levansucrase remaining associated with the cell wall (Chambert \& Petit-Glatron, 1984). After centrifugation, the pellets were washed with $0.5 \mathrm{ml} 0.1 \mathrm{M}$ sodium phosphate, $\mathrm{pH} 7$, containing the protease inhibitors. The pellets from this step were resuspended in $0.3 \mathrm{ml} 50 \mathrm{mM}$ Tris/ $\mathrm{HCl}, \mathrm{pH} 7 \cdot 4$, containing $5 \mathrm{mM}$ EDTA, $150 \mathrm{mM} \mathrm{NaCl}$ and $2 \%(\mathrm{w} / \mathrm{v})$ SDS. The cells were then disrupted by sonication, the suspensions were incubated for $5 \mathrm{~min}$ at $95^{\circ} \mathrm{C}$ and diluted in $1.7 \mathrm{ml}$ TNET (50 mM Tris/ $\mathrm{HCl}, \mathrm{pH} 7 \cdot 5$, containing $150 \mathrm{mM}$ $\mathrm{NaCl}, 5 \mathrm{mM}$ EDTA and $1 \%$, w/v, Triton X-100). Purified anti-levansucrase antibodies $\left(8 \mu \mathrm{l}, 4 \mathrm{mg} \mathrm{ml}^{-1}\right)$ and $80 \mu \mathrm{l} 10 \%$ Protein-A-Sepharose in TNET were then added and incubated overnight at $4{ }^{\circ} \mathrm{C}$. The immunoprecipitates were recovered by centrifugation. The pellets were washed three times with $1 \mathrm{ml}$ TNET, and finally resuspended in the electrophoresis sample buffer. After $5 \mathrm{~min}$ at $95^{\circ} \mathrm{C}$, the samples were analysed by SDSPAGE.

Culture and strains. Strains QB112 $\left(\operatorname{sac} A_{321} \operatorname{sau} U_{32}\right)$ and QB250 $\left[\operatorname{sac} A_{321} \operatorname{sac} U_{32} \operatorname{sac} B(250)\right]$ were grown in minimal medium supplemented with $1 \%(\mathrm{w} / \mathrm{v})$ glucose or $1 \%(\mathrm{w} / \mathrm{v})$ glycerol as carbon source (Petit-Glatron et al., 1993).

Gel electrophoresis and immunoblotting. Proteins were analysed on $10 \%$ SDS-polyacrylamide gels and the membraneassociated forms of levansucrase were analysed by immunoblotting under the conditions described previously (PetitGlatron et al., 1987).

Folding experiments. The unfolding-folding transitions of levansucrase were monitored by following changes in intrinsic fluorescence measured with a F2000 Hitachi thermoregulated spectrofluorimeter (Chambert \& Petit-Glatron, 1990).

Protein- $\mathrm{Ca}^{2+}$ binding assays. $\mathrm{Ca}^{2+}$ binding to levansucrase and $\alpha$-amylase was assayed by quantitative dot-blot (Maruyama et al., 1984) using ${ }^{45} \mathrm{CaCl}_{2}$ [specific activity $10 \mathrm{mCi}(370 \mathrm{MBq}$ ) $\mathrm{mg}^{-1}$ ] on nitrocellulose.

\section{RESULTS}

\section{In vitro unfolding-folding transition of levansucrase}

Modulation of the refolding kinetics by $\mathrm{pH}$ and calcium concentration. The kinetics of the unfolding-folding transition of levansucrase were followed by measuring the changes in the intrinsic fluorescence of the protein as previously described (Chambert \& Petit-Glatron, 1990). In a first set of experiments, the protein was unfolded in $8 \mathrm{M}$ urea at $30^{\circ} \mathrm{C}$. Refolding was promoted by dilution of the denaturing agent in $0.1 \mathrm{M}$ potassium phosphate buffer at a series of $\mathrm{pH}$ values from $5 \cdot 8$ to $7 \cdot 8$, which is in the range of physiological $\mathrm{pH}$ allowing normal $B$. subtilis growth. At each $\mathrm{pH}$ value, the kinetics of the transition were monitored in the absence or presence of $0.5 \mathrm{mM} \mathrm{Ca}^{2+}$ (Fig. 1). The protein displayed two different behaviours depending on the $\mathrm{pH}$. From $\mathrm{pH} 5.8$ to 6.8 , the rate of 


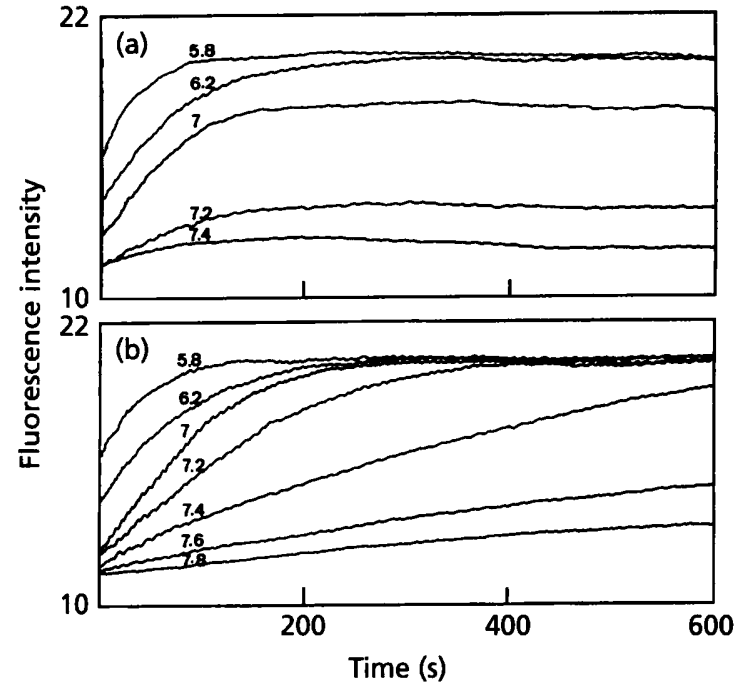

Fig. 1. Kinetics of levansucrase refolding with respect to the $\mathrm{pH}$ of the renaturation mixture at $30^{\circ} \mathrm{C}$. A sample of $1 \mu$ l stock solution of purified levansucrase $\left(5 \mathrm{mg} \mathrm{ml}^{-1}\right)$ was preincubated for $4 \mathrm{~min}$ in $20 \mu \mathrm{l} 8 \mathrm{M}$ urea at pH 7. Refolding was initiated by adding $1 \mathrm{ml} 0.1 \mathrm{M}$ potassium phosphate at the $\mathrm{pH}$ indicated, containing (a) $1 \mathrm{mM}$ EDTA, or (b) $0.5 \mathrm{mM}$ calcium. Fluorescence intensity was recorded after urea dilution. The 'dead' time was estimated to be $5 \mathrm{~s}$.

refolding decreased slightly and was not affected by $\mathrm{Ca}^{2+}$. At $\mathrm{pH} \geqslant 7$, the rate and the yield of refolding decreased strongly and became more calcium dependent as the $\mathrm{pH}$ value increased.

Effects of a small shift of pH or a jump in $\mathrm{Ca}^{2+}$ concentration on the transition. For these experiments, the amplitudes of the variations were chosen to correspond roughly to the differences in $\mathrm{H}^{+}$or $\mathrm{Ca}^{2+}$ concentrations between the two sides of the cytoplasmic membrane. Levansucrase was unfolded at $\mathrm{pH} 7 \cdot 4$ in the absence of $\mathrm{Ca}^{2+}$, which are the conditions usually prevailing in the cytosol (Khan \& Macnab, 1980). Refolding was promoted either by a small downward shift in $\mathrm{pH}$ or by the injection of $\mathrm{Ca}^{2+}$ in the renaturing mixture to give conditions simulating the environment of the external side of the membrane. When the $\mathrm{pH}$ was shifted from $7 \cdot 4$ to 6 , the refolding reaction monitored by variation of the intrinsic fluorescence of the protein was fast $\left(t_{\frac{1}{2}}=10 \mathrm{~s}\right)$ (Fig. 2a). Similar refolding kinetics were obtained when measuring refolding by the resistance to proteolytic degradation by subtilisin (Fig. $2 b)$. The transition occurred in the absence of $\mathrm{Ca}^{2+}$. With the $\mathrm{pH}$ maintained at $7 \cdot 4$, complete refolding was obtained at $5 \mathrm{mM} \mathrm{Ca}^{2+}$, but the rate of the unfolding-refolding transition increased as a function of the increase in $\mathrm{Ca}^{2+}$ concentration (Fig. 3).

Thus, we can conclude that small variations in $\mathrm{H}^{+}$or $\mathrm{Ca}^{2+}$ concentrations, compatible with physiological transmembrane $\mathrm{pH}$ or $\mathrm{Ca}^{2+}$ gradients, can significantly and rapidly displace the equilibrium between the unfolded and folded states of levansucrase.
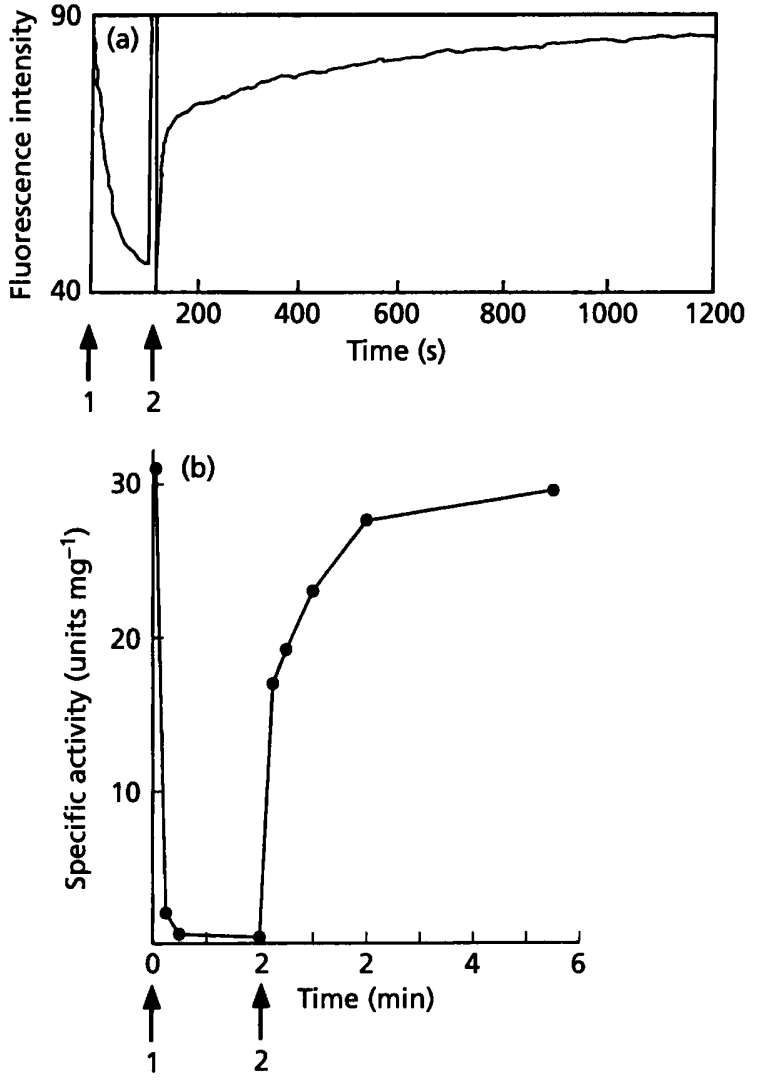

Fig. 2. Unfolding-refolding transition of levansucrase following a pH shift from 7.4 to 6.0 at $30^{\circ} \mathrm{C}$ in the presene of 1 mM EDTA. Levansucrase was unfolded by mixing (arrow 1) $5 \mu \mathrm{l}$ levansucrase stock solution $\left(5 \mathrm{mg} \mathrm{ml}^{-1}\right)$ with $1 \mathrm{ml} 0.1 \mathrm{M}$

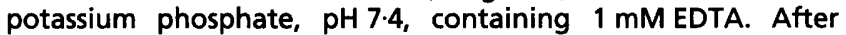
2 min of unfolding, the $\mathrm{pH}$ was shifted to 6.0 by the addition of $10 \mu \mathrm{l} 5 \mathrm{M}$ phosphoric acid (arrow 2). The kinetics of levansucrase unfolding and refolding were monitored by (a) the fluorescence intensity changes and (b) the resistance to subtilisin proteolytic degradation. Aliquots of $20 \mu \mathrm{l}$ were withdrawn at intervals and mixed with $10 \mu \mathrm{l}$ subtilisin solution $\left(1 \mathrm{mg} \mathrm{m}^{-1}\right)$. After $2 \mathrm{~min}$ incubation, $400 \mu \mathrm{l} 0.1 \mathrm{M}$ sucrose solution containing $0.2 \mathrm{mM}$ PMSF was added and sucrase activity was assayed. Subtilisin rapidly degrades the unfolded form of levansucrase but not the folded enzyme (Chambert et al., 1990).

\section{In vivo efficiency of the second step of levansucrase secretion is modulated by the $\mathrm{pH}$ and $\mathrm{Ca}^{2+}$ concentration of the growth medium}

The rate of $B$. subtilis growth is similar at all $\mathrm{pH}$ values within the range 5.8 to 7.8 . Since the in vitro folding properties of levansucrase differ greatly according to the external $\mathrm{pH}$ value, we have postulated that the folding properties of the transient processed membrane form of levansucrase might similarly vary. Thus, we evaluated the yield of levansucrase production, the kinetics of its release into the supernatant and its stability by pulse-chase experiments. We previously demonstrated that this type of experiment characterizes the kinetics of the second step of the secretion process (Chambert \& Petit-Glatron, 1988). 


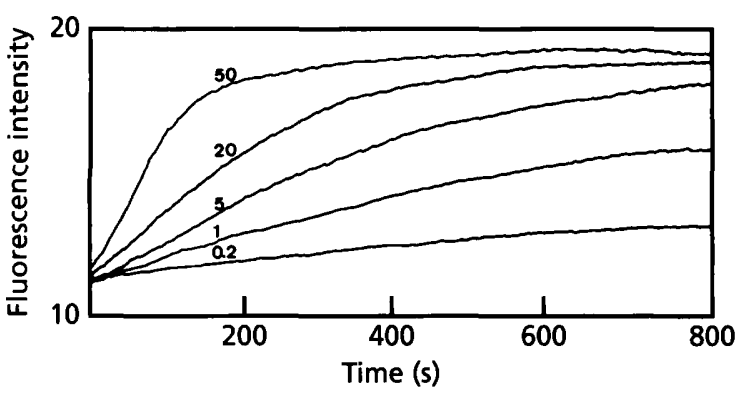

Fig. 3. Kinetics of levansucrase refolding at $\mathrm{pH} 7 \cdot 4$ and $30^{\circ} \mathrm{C}$ at various $\mathrm{Ca}^{2+}$ concentrations. A sample of $1 \mu \mathrm{l}$ purified levansucrase stock solution $\left(5 \mathrm{mg} \mathrm{ml}^{-1}\right)$ was preincubated for $4 \mathrm{~min}$ in $20 \mu \mathrm{l} 8 \mathrm{M}$ urea at $\mathrm{pH} 7 \cdot 4$. Refolding was initiated by adding $1 \mathrm{ml} 0.1 \mathrm{M}$ potassium acetate, $\mathrm{pH} 7.4$, containing various concentrations of calcium chloride. The ionic strength was held constant in each experiment by the addition of potassium chloride. The unfolding-refolding transition was measured by following intrinsic fluorescence intensity changes. Calcium concentrations $(\mathrm{mM})$ were $50,20,5,1,0.2$, as indicated on the traces.

At $30^{\circ} \mathrm{C}$, levansucrase production was ten times higher at pH 5.8 than at $\mathrm{pH} 7.8$ (Fig. 4a, b). The results demonstrated that it was the yield of the protein release which was affected at $\mathrm{pH} 7 \cdot 8$ and not the stability of the protein in the culture medium. As suggested by in vitro folding experiments, the spontaneous folding of levansucrase on the external side of the membrane may be too low at $\mathrm{pH} 7.8$ and thereby prevent efficient release. In contrast, folding and secretion appear to be optimally coupled at $\mathrm{pH} 5 \cdot 8$. However, these results may also have been due to an effect of $\mathrm{pH}$ on the synthesis and processing of the transient membrane forms of levansucrase. We therefore examined the steady-state concentration of these (a)
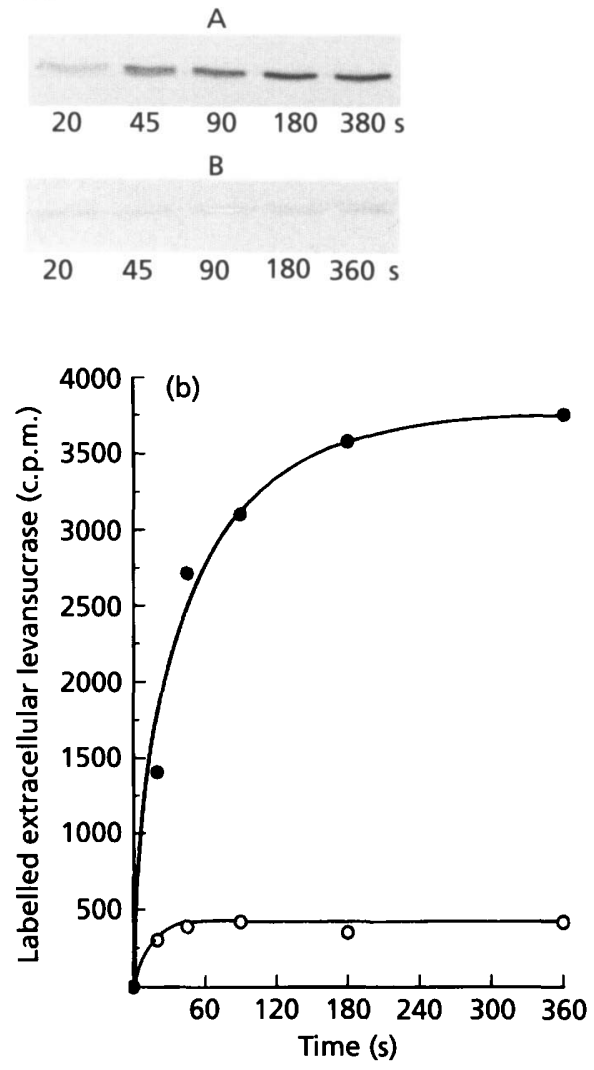

Fig. 4. Production of extracellular levansucrase by $B$. subtilis cultivated at pH5.8 or pH 7.8. (a) SDS-PAGE of labelled extracellular levansucrase from a pulse-chase experiment as described in Methods. A, Culture at $\mathrm{pH} 5.8$; $\mathrm{B}$, culture at $\mathrm{pH} 7.8$. Approximately the same amount of [35 S]methionine was incorporated in the bacteria at each $\mathrm{pH}$ during a pulse period of $1 \mathrm{~min}$. (b) Curves obtained by quantification of the radioactive bands from the SDS gels. O, Gel A; O, Gel B. (a)

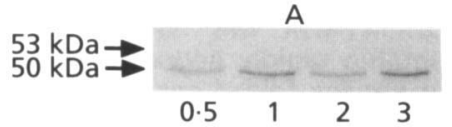

(b)

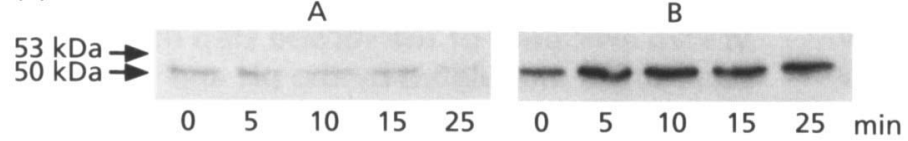

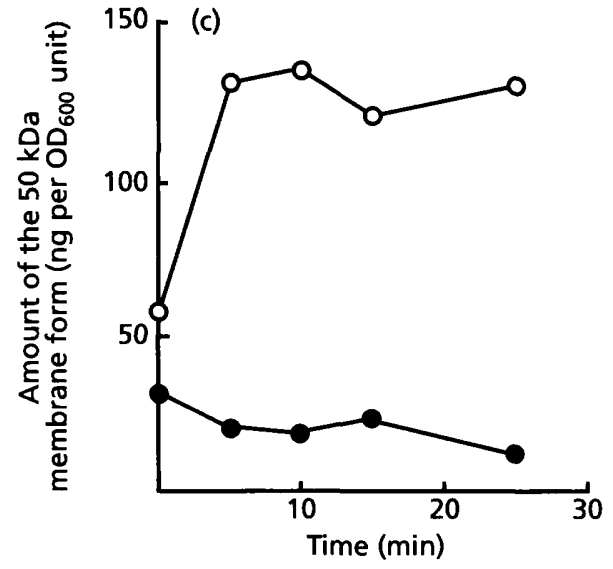

Fig. 5. Steady-state production of transient levansucrase membrane forms by $B$. subtilis grown at $\mathrm{pH} 5.8$ or $\mathrm{pH} 7.8$ and $30^{\circ} \mathrm{C}$. (a) Pulse experiment. Bacteria fully induced by sucrose were labelled with $\left[{ }^{35}\right.$ S]methionine at $\mathrm{OD}_{600} 2 \cdot 0$. Samples removed at the times indicated were treated and analysed as described in Methods. Immunoprecipitates of labelled levansucrase were obtained from bacteria grown at pH 5.8 (A) and pH 7.8 (B). Uptake of labelled methionine by bacteria was constant throughout the pulse period. (b) Immunoblotting. Bacteria grown at pH $5.8(\mathrm{~A})$ or $\mathrm{pH} 7.8(\mathrm{~B})$ and $30{ }^{\circ} \mathrm{C}$ were fully induced by sucrose $\left(50 \mathrm{mM}\right.$ final concn). After two generation times $\left(O_{600} 1.5\right) 5 \mathrm{mM}$ EDTA and 5 mM PMSF were added. Samples $(5 \mathrm{ml})$ were removed at the times indicated. Cell extracts were prepared for immunoblotting analysis as previously described (Petit-Glatron et al., 1987). (c) Quantification of immunoblotting analysis. O, Gel A; O, gel B. 
(a)
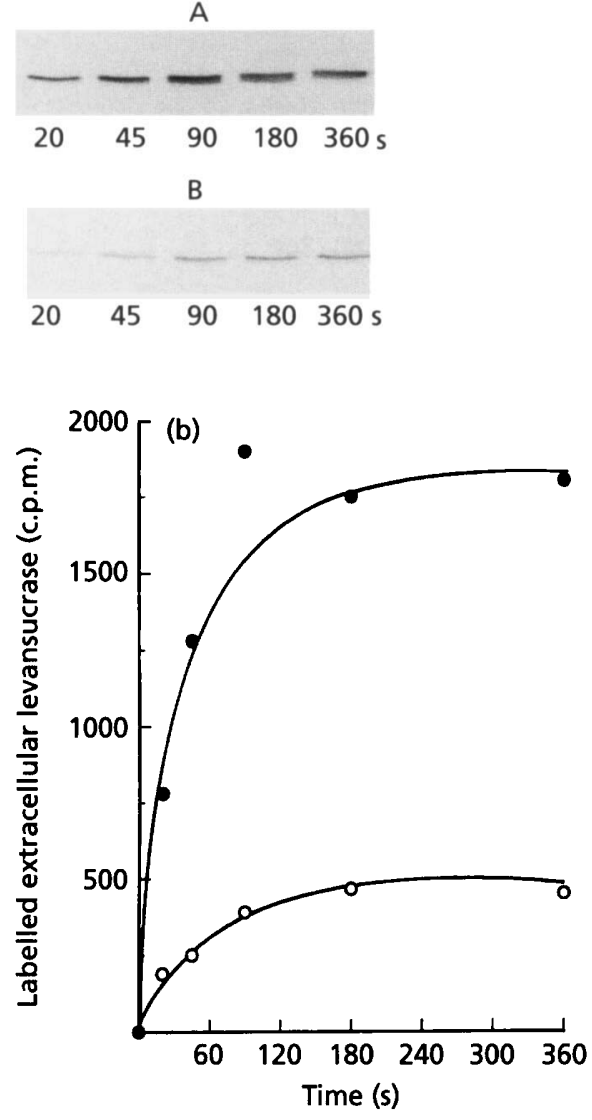

Fig. 6. Effects of $\mathrm{Ca}^{2+}$ on the production of extracellular levansucrase by $B$. subtilis grown at pH 7.4. (a) SDS-PAGE of labelled extracellular levansucrase from a pulse-chase experiment as described in Methods. A, Culture at $\mathrm{pH} 7.4$ in the presence of $0.2 \mathrm{mM} \mathrm{Ca}{ }^{2+} ; \mathrm{B}$, culture at $\mathrm{pH} 7.4$ with no added $\mathrm{Ca}^{2+}$. EDTA $(0.5 \mathrm{mM})$ was added to the culture $5 \mathrm{~min}$ before the pulse-chase. (b) Curves obtained by quantification of the radioactive bands from the SDS gels. O, Gel A; O, gel $B$.

intermediates by pulse experiments in bacteria grown at the two $\mathrm{pH}$ values (Fig. 5a). There were no significant differences either in the amount of labelled $50 \mathrm{kDa}$ membrane form or in the processing of prelevansucrase during the continuous uptake of $\left[{ }^{35} \mathrm{~S}\right]$ methionine. The fact that the cell-associated form was not accumulated at $\mathrm{pH} 7.8$ suggested that this unfolded form is proteolysed on the external side of the membrane rather than being folded and released. This hypothesis was substantiated by the strong accumulation of the $50 \mathrm{kDa}$ membrane form only observed at $\mathrm{pH} 7.8$ when two protease inhibitors, EDTA and PMSF, were added to the culture medium (Fig. 5b). The steady-state level of the $50 \mathrm{kDa}$ membrane levansucrase form was increased by a factor of three as evaluated by quantitative immunoblotting analysis (Fig. 5c).

To confirm the correlation between the efficiency of protein release and the ability to fold rapidly, we tested whether $\mathrm{Ca}^{2+}$ ions are involved in the coupling between these two events at defined $\mathrm{pH}$ values for which $\mathrm{Ca}^{2+}$ (a)
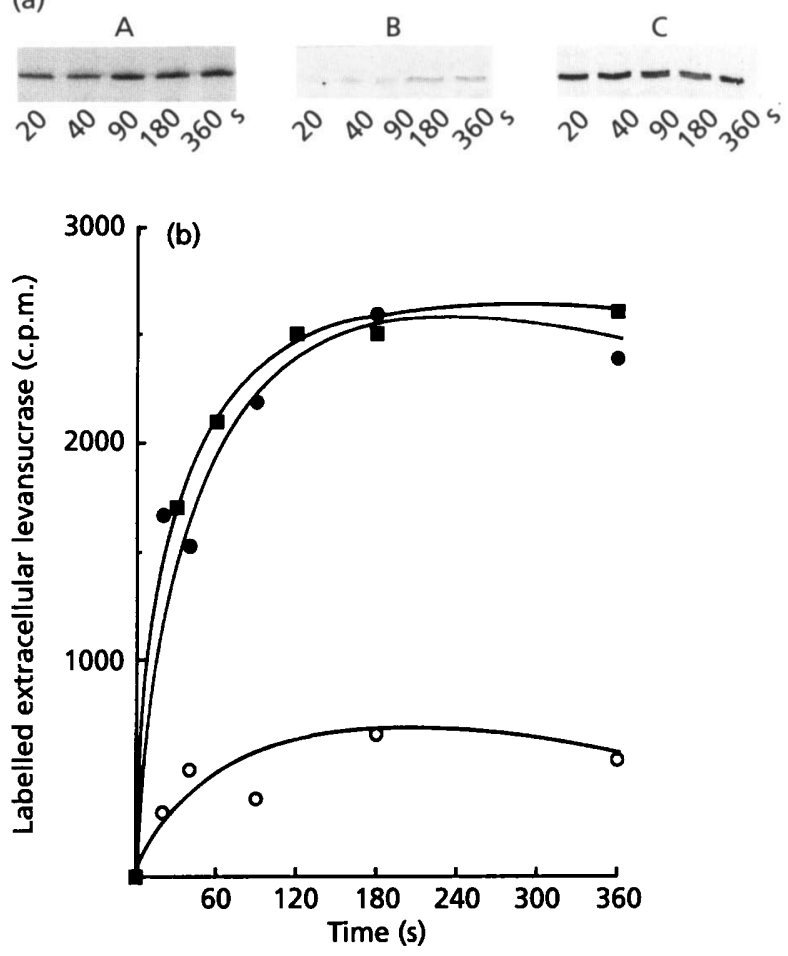

Fig. 7. Production of extracellular levansucrase by the mutant QB250 grown at $\mathrm{pH} 5.8$ and $\mathrm{pH} 7$ and $30^{\circ} \mathrm{C}$. (a) SDS-PAGE of labelled extracellular levansucrase from a pulse-chase experiment as described in Fig. 4. Production of extracellular wild-type levansucrase by strain QB112 grown at $\mathrm{pH} 7.0$ and $30^{\circ} \mathrm{C}$ (A) was compared with production of extracellular levansucrase by the mutant QB250 at $\mathrm{pH} 7$ (B) and $\mathrm{pH} 5.8$ (C) and $30^{\circ} \mathrm{C}$. (b) Curves obtained by quantification of the radioactive bands from the SDS gels. $\square$, Gel $A ; O$, gel $B ; 0$, gel c.

catalyses folding in vitro. The pulse-chase experiments were conducted with bacteria cultivated at $\mathrm{pH} 7 \cdot 4$. The culture medium was complemented with either $\mathrm{Ca}^{2+}$ $(0.2 \mathrm{mM})$ or the calcium chelator EDTA added at $5 \mathrm{mM}$, $5 \mathrm{~min}$ before the pulse. The yield of protein released into the extracellular medium was strongly dependent on the presence of free $\mathrm{Ca}^{2+}$ (Fig. 6a, b). A similar pulse-chase experiment carried out at $\mathrm{pH} 5 \cdot 8$ (result not shown) led us to conclude that $\mathrm{Ca}^{2+}$ is not required at this $\mathrm{pH}$ for efficient levansucrase secretion.

\section{A levansucrase variant with altered calcium-binding affinity is secreted normally at pH 5.8 and poorly at pH 7.0}

The amino acid at position 236 on mature levansucrase has been shown to play a crucial role in the unfoldingfolding transition, since residue 236 is part of a calciumbinding site. The amino acid substitution $\mathrm{Thr} \rightarrow \mathrm{Ile}$ at this position alters both the folding transition and the efficiency of secretion of levansucrase under standard conditions of $B$. subtilis growth ( $\mathrm{pH} 7)$. Increasing the $\mathrm{Ca}^{2+}$ concentration in the culture medium improves the yield of secretion of this variant (Petit-Glatron et al., 1993). 
(a)
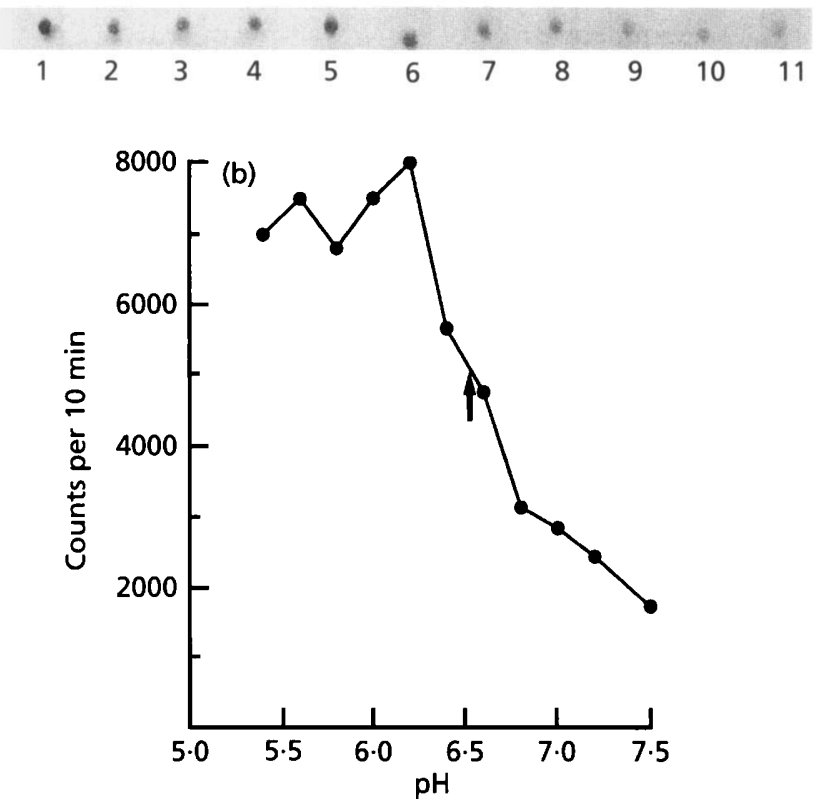

Fig. 8. Levansucrase calcium binding as a function of $\mathrm{pH}$. Samples of purified levansucrase $(2 \mu \mathrm{g})$ were blotted onto nitrocellulose. Each piece of membrane was equilibrated for $15 \mathrm{~min}$ at room temperature in buffer at $\mathrm{pH}$ varying from 5.4 to 7.5, and then incubated for $30 \mathrm{~min}$ in $1 \mathrm{ml}$ of the same buffer containing $20 \mu \mathrm{Ci}{ }^{45} \mathrm{CaCl}_{2}$. Each membrane was washed for $20 \mathrm{~min}$ in a large volume of the buffer and air-dried. The dried membranes were first exposed to Kodak X-Omat film then excised and their radioactivity measured. (a) Autoradiography of the nitrocellulose pieces treated at the following $\mathrm{pH}$ values $1,5.4 ; 2,5.6 ; 3,5.8 ; 4,6.0 ; 5,6.2 ; 6,6.4 ; 7,6.6 ; 8,6.8 ; 9,7.0 ; 10$, $7 \cdot 2 ; 11,7 \cdot 5$. (b) Graphic representation of the counts (means of three individual experiments) of the excised spots versus the $\mathrm{pH}$ of the incubation and washing buffers. The inflexion point at $\mathrm{pH} 6.5$ is arrowed.

The data presented in this work suggest that the secretion efficiency of the levansucrase variant $\left(\mathrm{Thr}_{236} \rightarrow \mathrm{Ile}_{236}\right)$ might be affected at $\mathrm{pH} \geqslant 7$ only and not at lower $\mathrm{pH}$ values because at lower $\mathrm{pH}$ the protein would not need the presence of $\mathrm{Ca}^{2+}$ ions for folding. As expected, variant 236 was secreted at $\mathrm{pH} 5.8$ with the same efficiency as the wild-type protein (Fig. 7a, gels $\mathrm{A}$ and C), whereas at $\mathrm{pH} 7$ its secretion efficiency was very low compared to wildtype levansucrase (Fig. 7a, gel B). These findings support the hypothesis that the efficiency of the second step of secretion is coupled to the folding event.

\section{$\mathrm{H}^{+}$and $\mathrm{Ca}^{2+}$ may cooperate to couple the folding and secretion events when bacteria are grown at high temperature}

We have shown above that $\mathrm{Ca}^{2+}$ is not required at $30^{\circ} \mathrm{C}$ for efficient protein secretion when the external $\mathrm{pH}$ of the growth medium is acidic enough. Thus, it appears that $\mathrm{Ca}^{2+}$ does not function as a folding catalyst at low $\mathrm{pH}$ values. We therefore tested the calcium binding affinity throughout the $\mathrm{pH}$ range 5.8 to 7.8 by the method of Maruyama (1984). Surprisingly, the protein displayed a (a)
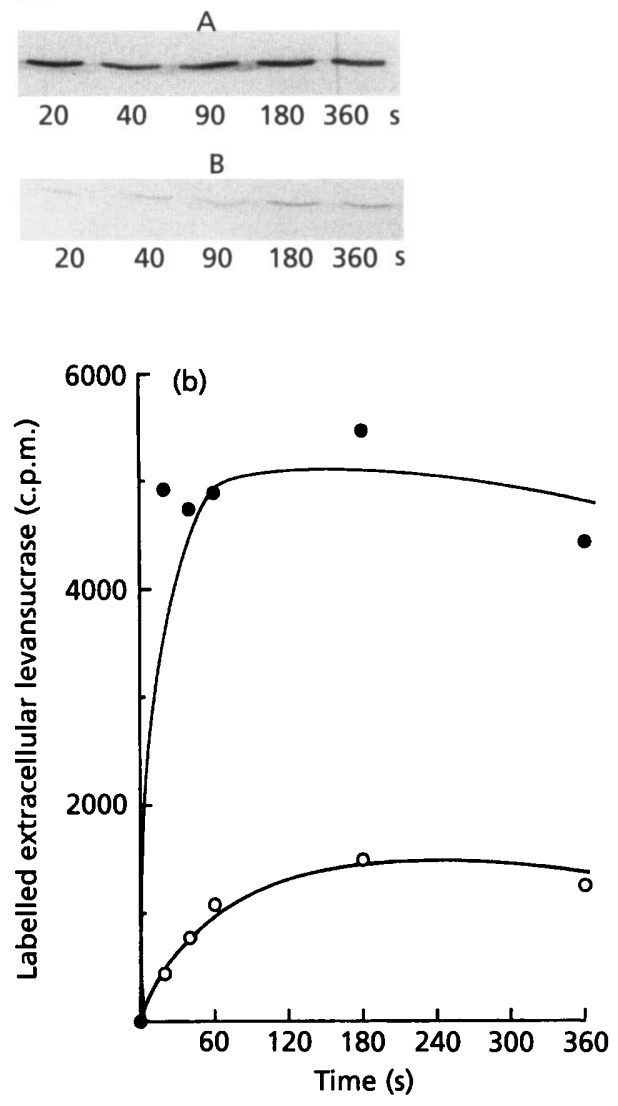

Fig. 9. Production of extracellular levansucrase by $B$. subtilis grown at $48^{\circ} \mathrm{C}$ at pH $5 \cdot 8$, in the absence or presence of $\mathrm{Ca}^{2+}$. (a) SDS-PAGE of labelled extracellular levansucrase from a pulsechase experiment as described for Fig. 5. A, Culture in the presence of $0.2 \mathrm{mM} \mathrm{Ca}{ }^{2+} ; \mathrm{B}$, culture with no $\mathrm{Ca}^{2+}$ added. EDTA $(0.5 \mathrm{mM})$ was added to the culture $5 \mathrm{~min}$ before the pulsechase. (b) Curves obtained by quantification of the radioactive bands from the SDS gels. 0 , Gel A; O, gel B.

higher affinity for $\mathrm{Ca}^{2+}$ at acidic $\mathrm{pH}$ (Fig. 8a). The calcium titration curve showed an inflexion point at pH 6.5 (Fig. $8 \mathrm{~b})$. This unexpected result suggests that $\mathrm{Ca}^{2+}$ and $\mathrm{H}^{+}$ concentrations could cooperate to promote an efficient coupling between folding and secretion under particular environmental conditions. We tested this possibility by pulse-chase experiments at high temperature since, in such conditions, levansucrase folding is very sensitive to $\mathrm{Ca}^{2+}$ and $\mathrm{H}^{+}$concentrations (Chambert \& Petit-Glatron, 1990). The efficiency of the final step of secretion in bacteria grown at $48^{\circ} \mathrm{C}$ and $\mathrm{pH} 5.8$ was significantly different in the presence and in the absence of $\mathrm{Ca}^{2+}$ (Fig. 9). The efficiency of the protein release and not its subsequent stability in the growth medium was modified by the presence of $\mathrm{Ca}^{2+}$.

\section{Is it possible to extend the effects of $\mathrm{pH}$ and $\mathrm{Ca}^{2+}$ on the secretion efficiency of other secretory proteins?}

Several difficulties arise in addressing the above question. Firstly, the secretion level of extracellular proteins is 


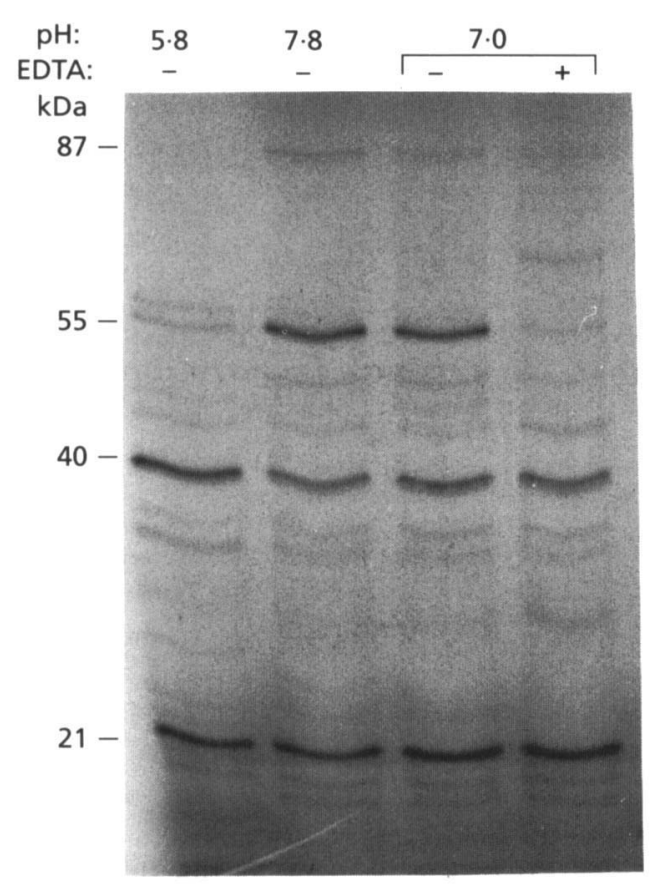

Fig. 10. Pattern of labelled exoproteins produced by $B$. subtilis 168 Marburg during the exponential phase of growth at various $\mathrm{pH}$ values. Bacteria grown at $\mathrm{pH} 5.8, \mathrm{pH} 7.8$ and $\mathrm{pH} 7.0$ were labelled for $5 \mathrm{~min}$ at $37^{\circ} \mathrm{C}$ with [ ${ }^{35} \mathrm{~S}$ ]methionine $\left(0.6 \mathrm{mCi} \mathrm{ml}^{-1} ; 1000 \mathrm{Ci} \mathrm{mmol}^{-1}\right)$ at $\mathrm{OD}_{600} 1.5$. A portion of bacteria grown at $\mathrm{pH} 7.0$ was labelled in the presence of $5 \mathrm{mM}$ EDTA. After centrifugation, aliquots of supernatants were directly analysed by SDS-PAGE. Molecular masses of the major labelled proteins are indicated on the left.

negligible in the $\operatorname{sac}_{32}$ strain used in this work during the exponential phase of growth (Chambert \& Petit-Glatron, 1984). Secondly, few data have hitherto been available concerning the folding properties of the $B$. subtilis secretory proteins. Given these limitations, we adopted two preliminary approaches to this question.

The first approach was based on the evaluation of the effects of medium parameters on the total production of extracellular proteins by a wild-type strain of $B$. subtilis (168 Marburg). The pattern of labelled exoproteins released by this strain was analysed by pulse experiments (Fig. 10) under the environmental conditions which modulate levansucrase production in strain QB112. Since in this experiment attention was given to other secretory proteins, bacteria were not induced for levansucrase synthesis. The modification of $\mathrm{pH}$, or the presence of a metal chelator, or both, modified the production of several exoproteins. One of these, a $55 \mathrm{kDa}$ protein, was dramatically modulated by these medium parameters, but in a different way from levansucrase in strain QB112.

For the second approach, we focused on the properties of extracellular $\alpha$-amylase, even though this protein is mainly produced during the stationary phase of growth. Folding properties of levansucrase and $\alpha$-amylase produced by the same $B$. subtilis strain were compared. The foldingunfolding transition of $\alpha$-amylase occurred at such a high

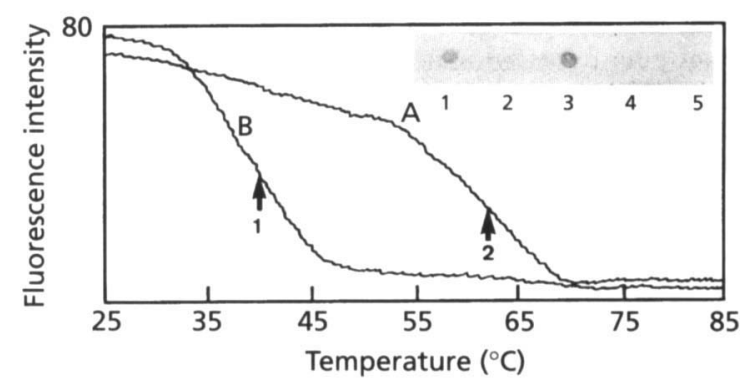

Fig. 11. The graph shows a comparison of the unfolding-folding transition of $\alpha$-amylase (curve A) and levansucrase (curve B). Thermal unfolding was followed by the intrinsic fluorescence intensity changes at $336 \mathrm{~nm}$. The excitation wavelength was $285 \mathrm{~nm}$. The protein concentrations were $1.5 \mu \mathrm{g} \mathrm{ml}^{-1}$ for $\alpha$-amylase and $4 \mu \mathrm{g} \mathrm{ml}^{-1}$ for levansucrase in $0.1 \mathrm{M}$ sodium phosphate, $\mathrm{pH}$ 7. The temperature of the protein solutions in the thermoregulated spectrofluorimeter cell was gradually increased from $25^{\circ} \mathrm{C}$ to $85^{\circ} \mathrm{C}$, at a constant rate of $2^{\circ} \mathrm{C}$ per $90 \mathrm{~s}$. Temperatures of the mid-point are indicated by arrow 1 for levansucrase and arrow 2 for $\alpha$-amylase. The inset shows calcium-binding properties of $\alpha$-amylase. Pure proteins $(1 \mu \mathrm{g})$ were blotted onto nitrocellulose. The radioactive dots corresponded to levansucrase (1), $\alpha$-amylase of $B$. subtilis (2), $\alpha$ amylase of $B$. licheniformis (3). The non-calcium-binding proteins BSA (4) and ovalbumin (5) were used as controls.

temperature $\left(T_{\mathrm{m}}=62^{\circ} \mathrm{C}\right)$ (Fig. 11a) that it was not reasonable to postulate that this protein has a tertiary structure flexibility similar to that exhibited by levansucrase under the conditions of $\mathrm{pH}$ and temperature of B. subtilis growth (Chambert \& Petit-Glatron, 1990). Moreover, the two proteins have very different affinities for calcium since no calcium binding was observed for $\alpha$ amylase (Fig. 11b) in contrast to levansucrase and Bacillus licheniformis $\alpha$-amylase. Furthermore, the secretion level of $\alpha$-amylase assayed in the culture supernatant during the exponential phase of $B$. subtilis growth at $\mathrm{pH} 5.8$ or 7.8 was not substantially different. These results seem to indicate that several different secretion mechanisms coexist in $B$. subtilis.

\section{DISCUSSION}

Bioenergetic aspects of the translocation of proteins across bacterial membranes have been the subject of many investigations (Palmen et al., 1994). There is also considerable evidence in both prokaryotic and eukaryotic systems that the dynamics and the free energy of protein folding play a role in the efficiency of secretion (London, 1992; Eilers \& Schatz, 1988). Several folding effectors have been identified in the cytosol which maintain the protein in a state competent for export (Kumamoto, 1991; Stuart et al., 1994; Baker \& Craig, 1994). Other effectors on the external side of the membrane assist the protein folding step which results in the irreversibility of translocation (Langer \& Neupert, 1991; Kontinen et al., 1991; Petit-Glatron et al., 1993). Thus, the chemical asymmetries between the cis and the trans sides of the membrane could be the driving forces for translocation, 
allowing the coupling of a scalar event (folding) with a vectorial event (translocation) (Simon et al., 1992).

Levansucrase of $B$. subtilis does not possess a prosequence, unlike the serine protease subtilisin (Otha et al., 1991) or $\alpha$-amylase (Sasamoto et al., 1989). These prosequences may play a role in the coupling of secretion and folding (Fujishige et al., 1992). There is no evidence that levansucrase undergoes a late chemical modification. Apparently it is the high conformational flexibility of levansucrase under the conditions of its synthesis in $B$. subtilis which allows it to be efficiently secreted.

$\mathrm{Fe}^{3+}$ or $\mathrm{Ca}^{2+}$ ions catalyse levansucrase folding at $\mathrm{pH} 7$. These ions are concentrated only on the external side of the membrane due to the metal-binding properties of the cell wall (Beveridge \& Murray, 1976, 1980; Petit-Glatron et al., 1993). The transmembrane gradient of these metal ions may be the force which drives the release of levansucrase from the membrane due to coupling with the folding process. However, this model can only apply to particular environmental conditions. Our studies suggest that the $\mathrm{H}^{+}$concentration on the external side of the membrane could play the same role as $\mathrm{Ca}^{2+}$ or $\mathrm{Fe}^{3+}$ ions.

However, this raises the issue of whether the $\mathrm{pH}$ on the external side of the membrane is the same as that in the bulk growth medium. Several theoretical and experimental analyses have shown that there is a very steep $\mathrm{pH}$ gradient between a very acidic interface layer which generates a surface electrostatic potential and the neutral bulk aqueous phase (Teissié et al., 1993; Koch, 1986). In the case of phosphatidylethanolamine bilayers, it was calculated that in a low ionic strength buffer $(1 \mathrm{mM})$ the drop was more than $2 \mathrm{pH}$ units across a distance of less than $1.5 \mathrm{~nm}$ (Prats et al., 1986). This phenomenon seemingly complicates the interpretation we propose. However the findings with model membranes may not apply to natural membranes. The $B$. subtilis cytoplasmic membrane contains a large amount of protein (about $60 \%$ dry weight), and relatively high proportions of cationic phospholipids (about 15\% lysylphosphatidylglycerol) (Archibald, 1993) and neutral glycolipids (Minnikin \& Abdeolrahimzadeh, 1974). This structural heterogeneity may greatly reduce the surface charge density which generates the electrostatic potential. Moreover, the magnitude of the potential is strongly dependent on the ionic strength (McLaughlin, 1977). In the ionic conditions of bacterial growth $(0 \cdot 1 \mathrm{M}$ potassium phosphate), this potential will be very low according to theoretical calculations; consequently, the $\mathrm{H}^{+}$concentrations on the bacterial membrane outer surface and in the bulk solution may not be very different.

On the other hand, our findings and interpretations have focused on the effects of $\mathrm{pH}$ and ions only on the proteins 'en route' to secretion, and not on the secretion machinery components. Obviously, this alternative must be considered as a reasonable working hypothesis even though experimental approaches are not easy. One possible heuristic way could be the comparison of in vitro and in vivo effects of these environmental parameters on PrsA activity, since this surface-exposed lipoprotein has been proposed to function as a molecular chaperone catalysing the folding of translocated secretory proteins such as $\alpha$-amylase (Kontinen et al., 1991) in B. subtilis.

\section{ACKNOWLEDGEMENTS}

We are grateful to EBSG (European Bacillus secretion group) for helpful discussions. We thank A. Edelman for help with the English text. This work was supported in part by a grant from the EEC (contract BIO2-CT93-0254).

\section{REFERENCES}

Archibald, A. R. (1993). The Bacillus cell envelope. In Bacillus, pp. 217-254. Edited by C. R. Harwood. New York: Plenum Press.

Baker, J. \& Craig, E. A. (1994). Heat shock proteins as molecular chaperones. Eur J Biochem 219, 11-23.

Beveridge, T. J. \& Murray, R. G. E. (1976). Uptake and retention of metals by cell walls of Bacillus subtilis. J Bacteriol 127, 1502-1518.

Beveridge, T. J. \& Murray, R. G. E. (1980). Sites of metal deposition in the cell wall of Bacillus subtilis. J Bacteriol 141, 1876-1887.

Chambert, R. \& Petit-Glatron, M. F. (1984). Hyperproduction of exocellular levansucrase by Bacillus subtilis: examination of the phenotype of a sac $U^{\mathrm{h}}$ strain. J Gen Microbiol 130, 3143-3152.

Chambert, R. \& Petit-Glatron, M. F. (1988). Secretion mechanism of Bacillus subtilis levansucrase: characterization of the second step. $J$ Gen Microbiol 134, 1205-1214.

Chambert, R. \& Petit-Glatron, M. F. (1990). Reversible thermal unfolding of Bacillus subtilis levansucrase is modulated by $\mathrm{Fe}^{3+}$ and $\mathrm{Ca}^{2+}$. FEBS Lett 275, 61-64.

Chambert, R., Benyahia, F. \& Petit-Glatron, M. F. (1990). Secretion of Bacillus subtilis levansucrase. Fe(III) could act as cofactor in an efficient coupling of the folding and translocation processes. Biochem J 265, 375-382.

Dedonder, R. (1966). Levansucrase from Bacillus subtilis. Methods Enzymol 8, 500-506.

Eilers, M. \& Schatz, G. (1988). Protein unfolding and the energetics of protein translocation across biological membranes. Cell 52, 481-483.

Fujishige, A., Smith, K. R., Silen, J. L. \& Agard, D. A. (1992). Correct folding of $\alpha$-lytic protease is required for its extracellular secretion from Escherichia coli. J Cell Biol 118, 33-42.

Hemila, H., Pokkinen, M. \& Palva, I. (1992). Improving the production of E. coli $\beta$-lactamase in Bacillus subtilis: the effect of glucose, $\mathrm{pH}$ and temperature on the production level. $J$ Biotechnol 26, 245-256.

Kemper, M. A., Urrutia, T. J., Beveridge, A. L. \& Doyle, R. J. (1993). Proton motive force may regulate cell wall associated enzymes of Bacillus subtilis. J Bacteriol 175, 5690-5696.

Khan, S. \& Macnab, R. M. (1980). Proton chemical potential, proton electrical potential and bacterial motility. $J$ Mol Biol 138, 599-614.

Koch, A. L. (1986). The $\mathrm{pH}$ in the neighborhood of membranes generating a protonmotive force. J Theor Biol 120, 73-84.

Kontinen, V. P., Saris, P. \& Sarvas, M. (1991). A gene $(\operatorname{prs} A)$ of Bacillus subtilis involved in a novel late stage of protein export. Mol Microbiol 5, 1273-1283.

Kumamoto, C. A. (1991). Molecular chaperones and protein translocation across the Escherichia coli inner membrane. Mol Microbiol 5, 19-22. 
Langer, T. \& Neupert, W. (1991). Heat shock proteins hsp60 and hsp 70: their roles in folding, assembly and membrane translocation of proteins. Curr Top Microbiol Immunol 167, 3-30.

London, E. (1992). How bacterial toxins enter cells: the role of partial unfolding in membrane translocation. Mol Microbiol 6, 3277-3282.

Măntsăla, P. \& Zalkin, H. (1979). Membrane-bound and soluble extracellular $\alpha$-amylase from Bacillus subtilis. $J$ Biol Chem 254, 8540-8547.

Maruyama, K., Mikawa, T. \& Ebashi, S. (1984). Detection of calcium binding proteins by ${ }^{45} \mathrm{Ca}$ autoradiography on nitrocellulose membranes after sodium dodecyl sulfate gel electrophoresis. $J$ Biocbem 95, 511-519.

McLaughlin, S. (1977). Electrostatic potentials at membrane-solution interfaces. Curr Top Membr Transp 9, 71-144.

Minnikin, D. E. \& Abdeolrahimzadeh, H. (1974). Effect of $\mathrm{pH}$ on the proportions of polar lipids in chemostat cultures of Bacillus subtilis. J Bacteriol 120, 999-1003.

Otha, Y., Hojo, H., Aimoto, S., Kobayashi, T., Zhu, X., Jordan, F. \& Inouye, M. (1991). Pro-peptide as an intramolecular chaperone: renaturation of denatured subtilisin $E$ with a synthetic pro-peptide. Mol Microbiol 5, 1507-1510.

Palmen, R., Driessen, A. J. \& Hellingwerf, K. J. (1994). Bioenergetic aspects of the translocation of macromolecules across bacterial membranes. Biocbim Biopbys Acta 1183, 417-451.

Petit-Glatron, M. F., Benyahia, F. \& Chambert, R. (1987). Secretion of Bacillus subtilis levansucrase: a possible two step mechanism. Eur $J$ Biochem 163, 379-387.
Petit-Glatron, M. F., Grajcar, L., Munz, A. \& Chambert, R. (1993). The contribution of the cell wall to a transmembrane calcium gradient could play a key role in Bacillus subtilis protein secretion. Mol Microbiol 9, 1097-1106.

Prats, M.. Teissié, J. \& Tocanne, J. F. (1986). Lateral proton conduction at lipid-water interfaces and its implications for the chemiosmotic-coupling hypothesis. Nature 322, 756-758.

Randall, L. L., Hardy, S. J. S. \& Tom, J. R. (1987). Export of protein: a biochemical view. Annu Rev Microbiol 41, 507-541.

Sasamoto, H., Nakasawa, K., Tsutsumi, K., Takase, K. \& Yamane, K. (1989). Signal peptide of Bacillus subtilis $\alpha$-amylase. J. Biochem 106, 376-382.

Shioi, J. I., Matsuura, S. \& Imae, Y. (1980). Quantitative measurements of proton motive force and motility in Bacillus subtilis. J Bacteriol 144, 891-897.

Simon, S. M., Peskin, C. S. \& Oster, G. F. (1992). What drives the translocation of proteins? Proc Natl Acad Sci US A 89, 3770-3774.

Somogyi, M. (1945). A new reagent for the determination of sugars. J Biol Chem 160, 61-73.

Stuart, R. A., Cyr, D. M., Craig, E. A. \& Neupert, W. (1994). Mitochondrial molecular chaperones; their role in protein translocation. Trends Biochem Sci 19, 87-92.

Teissié, J., Gabriel, B. \& Prats, M. (1993). Lateral communication by fast proton conduction: a model membrane study. Trends Biochem Sci 18, 243-246.

Received 30 August 1994; revised 28 December 1994; accepted 10 January 1995. 